\title{
Carrier state of Typhoid fever patient after treatment with chloramphenicol
}

Akmal Sya'roni, Zaini Dahlan
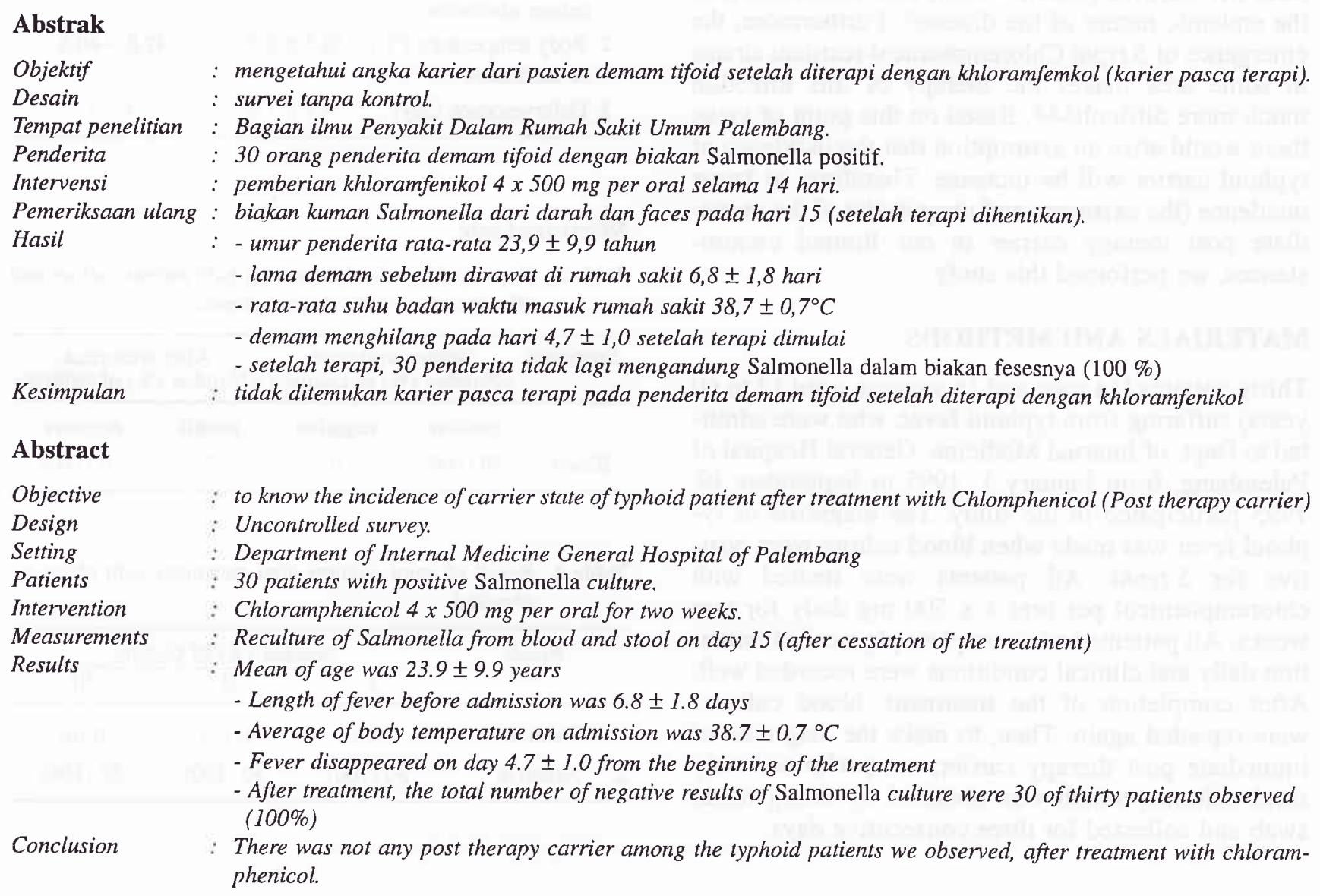

\section{INTRODUCTION}

Typhoid fever (TF) is still widespread and continues to be a global health problem, especially in developing countries. It's incidence is high in countries where there is neither a safe water supply nor adequate sanitation and spreads through contamination of food and water ${ }^{1,2}$. The incidence of typhoid fever in Indonesia is estimated about $360-810$ cases per 100.000 population per year ${ }^{3}$. In General Hospital of

Dept of Internal Med, General Hospital of Palembang/School of Medicine, Sriwijaya University Palembang, Indonesia.
Palembang, TF is still a common disease for which patients are admitted to Dept.of Internal Medicine ward.

Typhoid carrier is the ultimate source of infection, however it still remains a problem to be detected. Transmission of S.typhi in faeces is more important than transmission of this organism in urine. In connection with the therapy, typhoid carrier can be divided into 3 type: 4

Immediate Post therapy Carrier; excretion of S.typhi occurs within first week after treatment.

Transient Carrier; excretion of S.typhi within one month after treatment. 
Convalescent Carrier; excretion of S.typhi within 212 month after treatment.

Chloramphenicol is still drug of choice in the treatment of Typhoid fever, and in Indonesia this drug is used widely, especially throughout the Primary Public Health Centre. In 10\% cases, Chloramphenicol does not sterilize patient's stool, thus contributing to the endemic nature of the disease 2 . Furthermore, the emergence of S.typhi Chloramphenicol-resistant strains in some area makes the therapy of this infection much more difficult 2,5,6. Based on this point of view, there would arise an assumption that the incidence of typhoid carrier will be increase. Therefore, to know incidence (the existence and magnitude) of the immediate post therapy carrier in our limited circumstances, we perfomed this study.

\section{MATERIALS AND METHODS}

Thirty patients ( 14 men and 16 women, aged 13 to 60 years) suffering from typhoid fever, who were admitted to Dept. of Internal Medicine, General Hospital of Palembang, from January 1, 1995 to September 30, 1995 participated in the study. The diagnosis of typhoid fever was made when blood culture were positive for S.typhi. All patients were treated with chloramphenicol per oral $4 \times 500 \mathrm{mg}$ daily for two weeks. All patients had a complete physical examination daily and clinical conditions were recorded well. After completion of the treatment, blood cultures were repeated again. Then, to make the diagnosis of immediate post therapy carrier, we performed only stool cultures, which was obtained by doing rectal swab and collected for three consecutive days.

\section{RESULTS}

\section{Basic characteristic}

Table 1. Characteristics of Typhoid fever patients

\begin{tabular}{lcc}
\hline \multicolumn{1}{c}{ Variables } & Mean \pm SD & \multicolumn{1}{c}{ Range } \\
\hline 1. Age (years) & $23.9 \pm 9.9$ & $13-60$ \\
2. Height $(\mathrm{cm})$ & $159.6 \pm 8.6$ & $147-182$ \\
3. Weight $(\mathrm{kg})$ & $47.8 \pm 6.9$ & $30-61$ \\
\hline & No. of Men & No. of Women \\
4. Sex & $(\%)$ & $(\%)$ \\
\hline & $14(46.7)$ & $16(53.3)$ \\
\hline
\end{tabular}

\section{Clinical presentation}

Table 2. Mean and range of length of fever, defervescence, body temperature of Typhoid fever patients

\begin{tabular}{ccc}
\hline Variable & Mean \pm SD & Range \\
\hline $\begin{array}{l}\text { 1. Length of fever (day) } \\
\text { before admission }\end{array}$ & $6.8 \pm 1.8$ & $5-12$ \\
$\begin{array}{l}\text { 2. Body temperature }\left({ }^{\circ} \mathrm{C}\right) \\
\text { on admission }\end{array}$ & $38.7 \pm 0.7$ & $37.8-40.6$ \\
\begin{tabular}{l} 
3. Defervescence (day) \\
\hline
\end{tabular} & $4.7 \pm 1.0$ & $3-7$ \\
\hline
\end{tabular}

\section{Microbiologic}

Table 3. Results of blood cultures of typhoid patients before and after treatment with chloramphenicol

\begin{tabular}{ccccc}
\hline Specimen & \multicolumn{2}{c}{$\begin{array}{c}\text { Before treatment } \\
<\text { Number }(\%) \text { of culture }>\end{array}$} & $\begin{array}{c}\text { After treatment } \\
\text { Number }(\%)\end{array}$ & of culture $>$ \\
\hline \multirow{3}{*}{ Blood } & positive & negative & positif & negative \\
& $30(100)$ & 0 & 0 & $30(100)$ \\
\hline
\end{tabular}

Table 4. Result of stool cultures after treatment with chloramphenicol

\begin{tabular}{llccc}
\hline \multirow{2}{*}{ Result } & \multicolumn{3}{c}{ Number (\%) of Culture } \\
\cline { 2 - 4 } & & I & II & III \\
\hline 1. Positive & $0(0)$ & $0(0)$ & $0(0)$ \\
2. & Negative & $30(100)$ & $30(100)$ & $30(100)$ \\
\hline
\end{tabular}

\section{DISCUSSION}

As we have mentioned earlier, in connection with therapy, typhoid carrier can be divided into 3 types. One of them is immediate post therapy carrier, which excretes Salmonella typhi within one week after treatment. In our study we observed this type of typhoid carrier, because it is easier to control them in hospital setting.

Until now chloramphenicol remains as drug of choice in treating typhoid fever, but on the other hand chloramphenicol-resistant Salmonella typhi has appeared from time to time. Base on this view point, we performed this limited study to know the existence and magnitude of typhoid carrier. Thirty patients participated in this study, consisting of 14 men (46.7\%) and 16 women $(53.3 \%)$, aged $13-60$ years. 
In our study we found that length of fever before admission was $6.8 \pm 1.8$ days (range $5-12$ days) and and defervescence was $4.7 \pm 1.0$ days (range $3-7$ days). Our finding of these two variable did not differ so far with other investigators. Nelwan in his comparative study (chloramphenicol vs ofloxacin), for chloramphenicol group: Length of fever was 9.2 days (range $5-21$ days), defervescence was 4.4 days (range $2-6$ days) ${ }^{7}$. Soewandojo found that defervescence was $3.82 \pm 1.70$ days in chloramphenicol group 8 . Morelli also found that defervescence was 3.5 days (range $2-5$ days) ${ }^{2}$.

There wasn't any post therapy carrier found in our study, but in another study, Nelwan found 1 carrier out of 23 chloramphenicol-treated patients 7 . Soewandojo found 1 carrier out of 17 chloramphenicoltreated patients ${ }^{8}$. Morelli found 4 carriers out of 30 chloramphenicol- treated patients ${ }^{2}$. These differences of findings among those studies might be caused by the difference of methodology.

\section{CONCLUSION}

In this limited study, we didn't find any post therapy carrier after treatment with chloramphenicol.

\section{REFERENCES}

1. Setyawan H, Hadi Saputro S: Risk factor for Typhoid fever, a case-control study in Indonesia, Acta Medica Indonesiana 1996: 145-50.

2. Morelli G, Mazzoli S, Tortoll E et al. Fluoroquinolones versus Chloramphenicol in the therapy of Typhoid fever: a clinical and microbiological study, Current Therapeutic Research 1992; 52(4): 532-41.

3. Simanjuntak CH. Demam Tifoid; Epidemiologi dan perkembangan penelitiannya, Cermin Dunia Kedokteran 1993; 83: $52-4$.

4. Sujanto E, Kaspan MF, Parwati SB. Typhoid Carrier, Majalah Kedokteran Indonesia 1982; 32(32): 44-50.

5. Wahyono H, Isbandrio B, Gassem HM et al. Pola Kepekaan Kuman S.typhi, Majalah Dokter Keluarga 1991; 10(11): 226

6. Rao PS, Rajashekar V, Varghese GK, Shivananda PG. Emergence of multidrug-resistant Salmonella typhi in rural Soythern India, Am J Trop Med Hyg 1993; 48(1): 108-11.

7. Nelwan RHH, Widjanarko A, Hendarwanto, Zulkarnain I, Gunawan J. Studi komparatif terkontrol menggunakan Ofloksasin pada Demam Tifoid, Simposium Terapi Mutakhir Demam Tifoid, Jakarta 1992

8. Soewandojo, et al. Uji banding Ciprofloxacin - chloramphenicol pada pengobatan demam tifoid, Naskah lengkap KOPAPDI VIII Jogyakarta 1993: 731-5. 